\title{
Studies on carotenoids and oxidative stability of winter squash seed and soybean oils
}

\author{
By H.E. Helmy \\ Oil and Fats Department. National Research Centre. Dokki. Cairo. EGYPT
}

RESUMEN

Estudios sobre carotenoides y estabilidad oxidativa de aceites de semilla de calabaza de invierno y de soja.

Se han extraido con hexano comercial aceites de semilla de calabaza y de soja. Usando análisis espectrofotométrico y cromatografia en capa fina se han estudiado en estos aceites tres tipos de pigmentos: carotenoides, principalmente luteina y B-caroteno, clorofilas y otros no identificados. Los contenidos en carotenoides fueron 70,60. $0 \mathrm{ppm}$ en aceite de semilla de calabaza de invierno crudo, refinado y decolorado. y $80,65,0 \mathrm{ppm}$ en aceite de soja crudo, refinado y decolorado respectivamente.

Se ha evaluado la estabilidad de aceites de semilla de calabaza de invierno, soja y una mezcla 1:1 de ambos, en sus estados crudo. refinado y decolorado. La mezcla de semilla de calabaza de invierno con aceite de soja aumentó la estabilidad de este último. El aceite crudo mostró una mayor estabilidad que los aceites refinados y decolorados.

PALABRAS-CLAVE: Aceite de semilla de calabaza de invierno - Aceite de soja - Carotenoide - Clorotila - Estabilidad oxidativa.

\section{SUMMARY}

Studies on carotenoids and oxidative stability of winter squash seed and soybean oils.

Winter squash seed and soybean oils were extracted with commercial hexane. Carotenoids and other pigments in the oils were studied using spectrophotometric and thin layer chromatographic analysis. Three types of pigments were identified: carotenoids. mainly luteın and B-carotene, chlorophyll and some unidentified pigments. Carotenoids content were $70,60,0 \mathrm{ppm}$ in crude, refined and bleached winter squash seed oil, and $80,65,0 \mathrm{ppm}$ in crude, refined and bleached soybean oil respectively.

Stability was evaluated for crude, refined and bleached winter squash seed and soybean oils and an 1:1 admixture. Mixing winter squash seed oil with soybean oil increased the stability of soybean oil. Crude oil showed greater stability than refined and bleached oils.

KEY-WORDS: Carotenoid - Chlorophyll - Oxidative stability Soybean oil - Winter squash seed oil.

\section{INTRODUCTION}

Economic value of the seed oil protein of gourds "squashes" "Cucurbita sp."; has been recognized (Shahani, 1951). The oil is characterized as a semi-drying oil similar to soybean oil (Bolley, 1950). Although the crude oil has a dark colour, processed oil has good stability and does not undergo flavor reversion. Oil content of squash- es ranges from $35-41 \%$ has properties similar to commercial vegetable oils (Vasconcellos, 1980).

Pigments of the winter squash seed oil "Cucurbita maxima" were investigated and the oil was shown to be rich in carotenoids (Helmy, 1990). Preliminary experiments indicated that processing conditions could be selected to produce an oil equivalent in colour to commercial vegetable oils (Vasconcellos, 1982).

The purpose of this investigation was to morefully characterize the carotenoids in detail and to study their effect on the oxidative stability of crude, refined and bleached oils of winter squash seed, soybean and an 1:1 admixture.

\section{EXPERIMENTAL}

Oils of winter squash seed (Cucurbita maxima) and soybean (Glycina max.) were extracted for 6 hrs from the ground sieved fine particles of the seed kernels, with com. hexane in a Soxhelt apparatus. The solvent was then stripped from the miscella under vacuum at $50^{\circ} \mathrm{C}$ in a rotary evaporator.

Refining and Bleaching of Oil: Crude winter squash seed and soybean oils and an 1:1 admixture were refined and bleached according to the AOCS Official Methods (1980).

Refining: Fifty gm each of crude oils were placed in $200 \mathrm{ml}$ beakers and heated to $60^{\circ} \mathrm{C}$. The calculated amount of $\mathrm{NaOH}$ solution ( $18^{\circ} \mathrm{Bé}$ ) was added to crude oil during stirring for $15 \mathrm{~min}$., centrifuged at $3000 \mathrm{rpm}$, washed with warm water, recentrifuged, then decanted.

Bleaching: Fourty $\mathrm{gm}$ each of the refined oils was taken in $200 \mathrm{ml}$ flask and heated in an oil bath at $110^{\circ} \mathrm{C}$. Bleaching earth "Tonsil" was added at $3 \%$ of the oil weight while stirring for $10 \mathrm{~min}$. The clay was separated by centrifugation after cooling and the oil was recovered by decantation.

Spectrophotometric Analysis: Absorption spectra of crude, refined and bleached oils of winter squash seed, soybean and an 1:1 admixture was measured in a Shimadzu UV-Visible Spectrophotometer, Model UV-240 Graphtcord (Tokyo, Japan). Wavelength range from 300- 


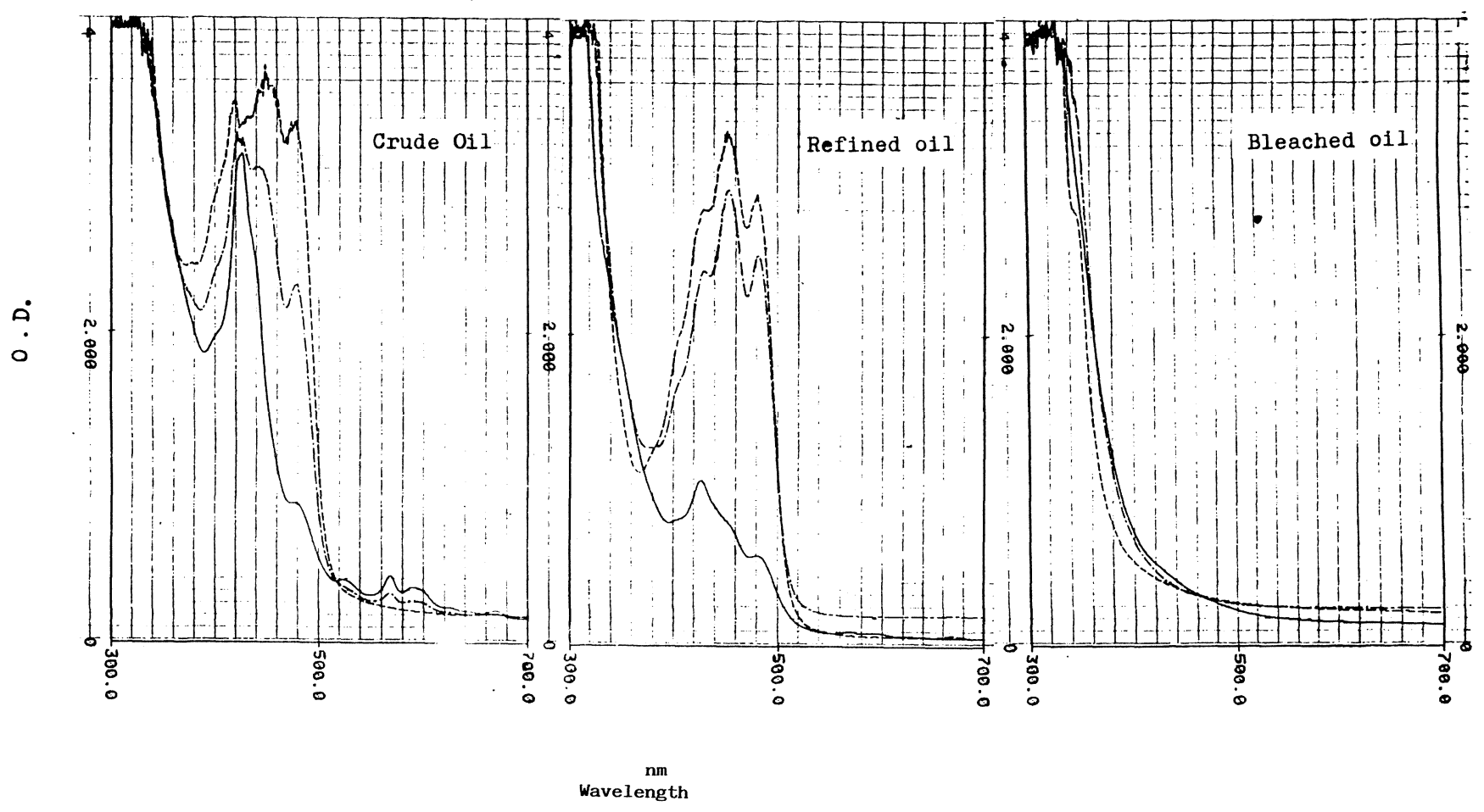

Figure 1

Absorption spectra of crude, refined and bleached winter squash seed $(-)$, soybean $(--)$ oils and on $1: 1$ admixture $(-\cdots)$.

$700 \mathrm{~nm}$ was used. Total carotenoids were determined according to Franzke (1973).

Color Evaluation: Oil color was evaluated in a Lovibond Tintometer using an 1 cuvette. The color was expressed in yellow $(Y)$ and red $(R)$, as described in the AOCS method.

Thin Layer Chromatographic Analysis (TLC): Carotenoids of winter squash seed and soybean oils were identified using t.l.c. chromatographic plates $(10 \times 20 \mathrm{~cm})$ coated with silica gel $G$ and developed with a solvent mixture of benzene-ethyl acetate-ethanol (80:20:5, v/v/v) as described by Seliskar (1966).

Oxidative Stability: Crude refined and bleached oils of winter squash seed, soybean and an 1:1 admixture, were placed in $100 \mathrm{ml}$ beakers and subjected to heating in an oven at $100^{\circ} \mathrm{C}$ for 4 days. Peroxide value was determined daily according to the Official AOCS Method.

\section{RESULTS AND DISCUSSION}

Absorption spectra of soybean and winter squash seed oils is illustrated in figure 1.

Winter squash seed oil exhibits three types of pigments, carotenoids, chlorophyll and unidentified pigments.
The carotenoids appeared at the wavelengthes 425,455 and $480 \mathrm{~nm}$. They were mainly lutein and B-carotene. The chlorophyll appeared at the wavelength $680 \mathrm{~nm}$. The unidentified pigments appeared at 525,570 and $590 \mathrm{~nm}$. They may belong to flavonoids (O'Connor, 1949).

Soybean oil exhibits same carotenoids (lutein and Bcarotene) at the wavelengthes 425,455 and $480 \mathrm{~nm}$, and same chlorophyll at $670 \mathrm{~nm}$. Yet it didn't contain the unidentified pigments appeared in winter squash seed oil.

Total content of carotenoids was 70,60 and $0 \mathrm{ppm}$ in crude, refined and bleached winter squash seed oils against 80,65 and $0 \mathrm{ppm}$ in crude, refined and bleached soybean oil respectively. It can be noticed that refining

Table I

Oil Color in Lovibond Units

\begin{tabular}{llrr}
\hline \multicolumn{1}{c}{ Oil } & Crude & Refined & Bleached \\
\hline Winter squash $(W)$ & $13 Y+1,1 R^{*}$ & $12 Y+0,8 R$ & $2 Y+0,1 R$ \\
Soybean $(S)$ & $10 Y+2 R$ & $10 Y+0,4 R$ & $1 Y+0,1 R$ \\
$1: 1(W-S)$ & $13 Y+2 R$ & $11 Y+0,8 R$ & $1 Y$ \\
\hline
\end{tabular}

$\cdot Y=$ Yellow, $R=$ Red 


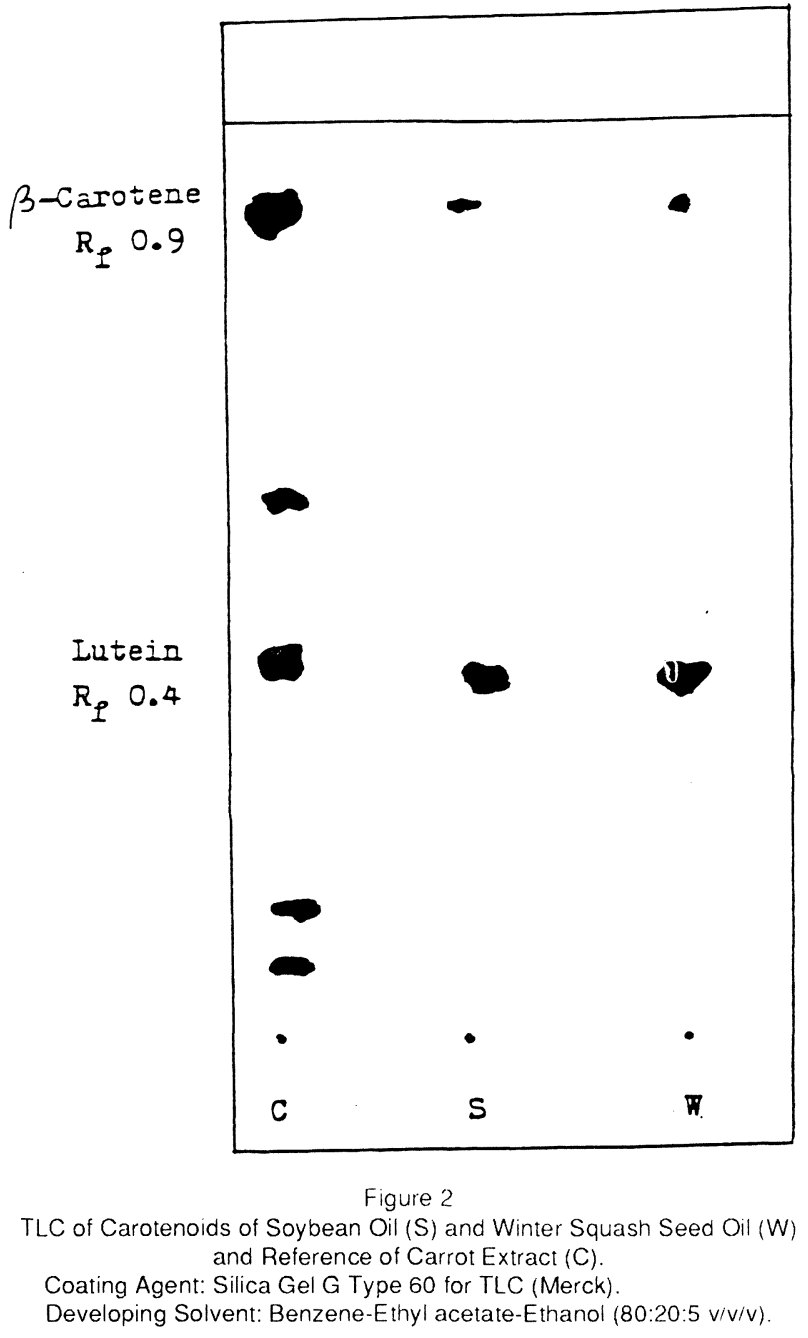

slightly lessened carotenoids, whereas bleaching completely removed them.

Color of the crude, refined and bleached winter squash seed and soybean oils and of an 1:1 admixture in Lovibond units is illustrated in table I.

Color of winter squash seed oil approached color of soybean oil. Lovibond color of the bleached oils ranged between $1 Y$ to $2 Y+0,1 R$. The refined oils were slightly lesser in color than the crude oils, particularly in red units which gave $2 R$ for crude against $0,4 R$ for refined oils.
Carotenoids in winter squash seed and soybean oils were further characterized by TLC. The results are shown in figure 2.

Two components of carotenoids were identified in winter squash seed and soybean oils; lutein with $R_{t}$ value of 0.4 and $B$-carotene with $R_{t}$ value of 0.9 .

Oxidative stability was determined for crude, refined and bleached oils of soybean, winter squash and an 1:1 admixture. The purposes of using the oils in the form of crude, refined and bleached are 1) to remove the effect of the fatty acid composition on the oxidative stability, because refining and bleaching of crude oils do not change fatty acid composition and 2) to magnify the effect of carotenoids in the oils, where carotenoids were 80 and $70 \mathrm{ppm}$ in crude w.squash and soybean oils and $0 \mathrm{ppm}$ in their bleached oils. Oxidative stability evaluated is illustrated in table II.

Results revealed that:

1. In crude soybean oil peroxide value jumped from 62,7 to 386,7 (516,7\% increase) after 3 days of heating against $101,3 \%$ increase in crude winter squash seed oil and only $22,6 \%$ increase in the admixture of soybean winter squash seed oil. Admixing crude winter squash seed oil with crude soybean oil potentiated stability of the later.

After 4 days of heating, peroxide value decreased in crude soybean in from 386,7 to 208,0 , where rate of decomposition of formed peroxide increased than rate of formation. At same peroid, peroxide value did not decrease in crude winter squash seed oil and in soybean/ winter squash seed oil admixture. This mean that their stability was more higher than crude soybean oil.

2. Refined soybean oil showed $202,0 \%$ increase in peroxide value against $378,3 \%$ increase in w.squash seed oil and $209,5 \%$ increase in soybean/w. squash seed oil admixture, after 2 days of heating. Then curves of peroxide value began to decline at the third day owing to the increase in the rate of decomposition of peroxide than the rate of formation.

3. Bleached soybean oil showed the highest peroxide value $(496,1)$ after two days of heating. Peroxide value was also high in w.squash seed oil $(456,1)$ and in soybean/w. squash seed oils $(486,6)$. After then peroxide value began to decrease.

Table II

Effect of Accelerated Storage on the Oxidative Stability of Winter-Squash Seed and Soybean Oils

\begin{tabular}{|c|c|c|c|c|c|c|c|c|c|}
\hline \multirow{2}{*}{$\begin{array}{c}\text { Oil } \\
\text { Days } \\
\text { Storage }\end{array}$} & \multicolumn{3}{|c|}{ Winter squash } & \multicolumn{3}{|c|}{ Soybean } & \multicolumn{3}{|c|}{ 1:1 admixture } \\
\hline & C & $\mathrm{R}$ & $\mathrm{B}^{\star}$ & C & $R$ & B & C & $\mathbf{R}$ & B \\
\hline Fresh & 7,5 & 8,9 & 9,5 & 6,3 & 8,5 & 8,8 & 7,0 & 8,1 & 9,3 \\
\hline 1 & 53,4 & 76,5 & 138,0 & 60,1 & 141,7 & 162,1 & 51,4 & 135,1 & 165,0 \\
\hline 2 & 62,3 & 365,9 & 456,1 & 62,7 & 427,9 & 496,1 & 57,4 & 418,2 & 486,8 \\
\hline 3 & 125,4 & 364,4 & 298,9 & 386.7 & 373,4 & 325,8 & 70,4 & 350,6 & 191,7 \\
\hline 4 & 172,2 & 346,7 & 291,0 & 208,0 & 289,5 & 311,9 & 161,1 & 277,8 & 151,7 \\
\hline
\end{tabular}

- $\mathrm{C}=$ Crude, $\mathrm{R}=$ Refined, $\mathrm{B}=$ Bleached . 
4. The rancidity began to appear clearly when the peroxide value reached to the maximum, where the carbonyls started to increase largely forming rancid odour. This characteristic can be explained as follows:

a) In winter squash seed oil rancidity began to appear in the refined oil after two days of heating $(365,9$ P.V.), and in the bleached oil after two days (456,1 P.V.), and did not appear after four days of heating in the crude oil.

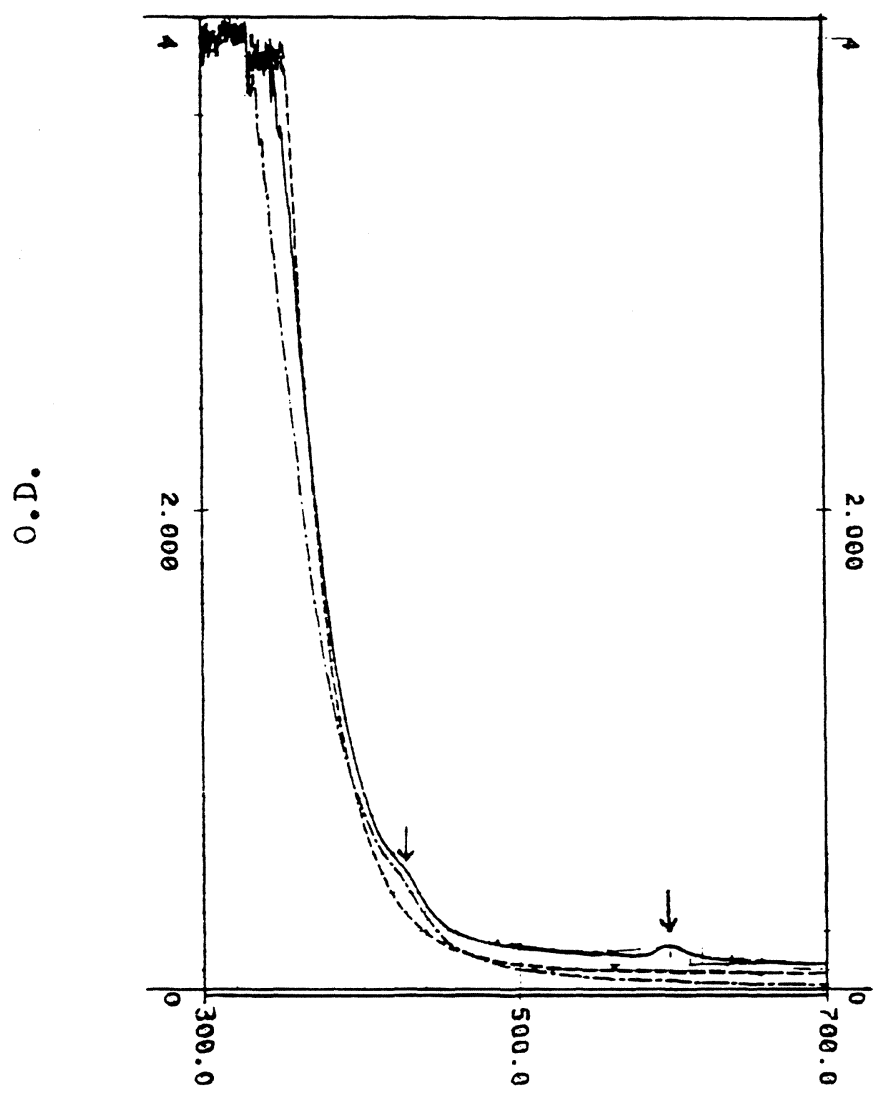

$\mathrm{nm}$

wavelength

Figure 3

Absorption spectra of crude winter-squash seed $(-)$, soybean $(---)$, olis and a $1: 1$ mixture $\left(\ldots \ldots\right.$ ) after four days of $100^{\circ} \mathrm{C}$ heating b) In soybean oil rancidity began to appear at 386,7 P.V. in the crude oil after three days of heating against 427,9 and 496,1 for the refined and bleached oils after two days.

c) Same was noticed for the 1:1 admixture where rancidity began to appear in the refined mixture at 418,2 P.V. after two days of heating and at 486,8 in the bleached mixture. This rancid odour was not appear in the crude oil.

Previous results revealed that crude oil is more stable than refined and bleached oils. Bleached oil was the lowest in stability, therefore it's advisable to add antioxidant to bleached oil. The results, also, revealed that winter squash seed oil was more stable than soybean oil, therefore mixing previous oils increased stability.

Figure 3 showed that carotenoids in the crude oils were destroyed after four days of heating except a small amount of residual lutein in the crude oil of winter squash seed at $425 \mathrm{~nm}$. It is possible that lutein (3,3 dihydroxy $\alpha$ carotene) is more stable than $B$-carotene, because it contains two hydroxy groups. Another small portion of the unknown pigment appeared at $600 \mathrm{~nm}$.

\section{REFERENCES}

Bolley, D S., MCCormack, R.H. and Curtis, L.C. (1950).- "The utilization of the seeds of the wild peremiat gourds".- J. Am. Oil Chemists' Soc. 27,571 .

Franzke, Cl., Grunert, S. and Kroschel, H. (1973).- "Importance of carotenoid and chlorophyll coloring agents in fat industry".- Nahrung 17. 587

Helmy, H.E. (1990) - "Studies on the pigments of some citrus, prune and cucurbita seed oils when processed with or without cottonseed oil".J. Am. Oil. Chemists' Soc. 67, 376.

O'Connor, R. T. Field. E.T., Jefferson, M.E. and Dollear, F.G. (1949)."The influence of processing on the spectral properties of vegetable oils". - J. Am. Oil Chemists' Soc. 26, 710.

"Official and Tentative Methods of the AOCS" (1980).- 3rd. ed., AOCS Champaign, IL

Seliskar, C.J. (1966).- - Separation of phytylated and non-phytylated chlorophylls by TLC".- Anal. Biochem. 17, 174.

Shahani, H.S., Dollear, F.G., Markley, K.S. and Quimby, J.R. (1951)."The Buffalo gourd, a potential oilseed crop of the Southwestern Drylands".- J. Am. Oil. Chemists' Soc. 28, 90.

Vasconcellos, J.A., Berry, J.W.. Weber, C.W., Bemis, W.P. and Scheerens, J.C. (1980).- "The properties of cucurbita foetidissima seed oil".J. Am. Oil Chemists' Soc. 57, 310.

Vasconcellos, J.A. and Berry, J.W. (1982).- "Characteristics of laboratory processed cucurbita foetidissima seed oil".- J. Am. Oil Chemists' Soc. 59,79

(Recibido: Diciembre 1991) 